\title{
The Mediterranean: Not a Union, but an Integrated Space?
}

\author{
Birlikten Ziyade Entegre Bir Bölge: Akdeniz
}

\section{Deniz GENÇ ${ }^{*}$ Erhan DOĞAN**}

\begin{abstract}
This study examines several multilateral cooperation initiatives in the Mediterranean and by discussin $\mathrm{g}$ their failures in generating a genuine cooperation, it hypothesizes about an integrated Mediterranean space, where prime challenges might lead to a loose functional framework of integration. In putting forward this hypothetical integrated space, the study begins with discussing prime challenges in the region: security, migration and environment, and it proceeds with early multilateral cooperation attempts. Among these, it focuses its attention on two ambitious ones: Euro-Mediterranean Partnership and the Union for the Mediterranean, and underlines the disappointments in these attempts in realizing peace and prosperity in the region. The study concludes that an integrated space in the Mediterranean, which takes European integration experience as a model, might offer a better solution to the common problems in the region with a precondition that southern Mediterranean states are provided a clear perspective in a sincere and equal partnership.
\end{abstract}

Keywords: Mediterranean, cooperation, security, migration, environment, integration, space

Öz

Bu çalışma Akdeniz'deki çeşitli çok taraflı işbirliği çabalarını ele almakta ve bu işbirliği çabalarının samimi bir işbirliği tesis etme konusundaki başarısızlıklarını ortaya koymaktadır. Yazı Akdeniz’de öncelikli sorunlara odaklı gelişecek dinamiklerin gevşek bir işlevsel entegrasyon çerçevesine olanak tanıyabileceği hipotezini ileri sürer ve bölgedeki güvenlik, göç ve çevre gibi temel sorunları tartışır. Ardından, bu sorunların çözümüne yönelik erken işbirliği çabalarını ele alır. Bu işbirliği çabaları arasından, iki iddialı projeye, "Avro-Akdeniz Ortaklığı" ve "Akdeniz için Birlik"e odaklanır. Her iki projenin de bölgede barışı ve refahı sağlama konusunda beklentileri karşılayamadığının altını çizer. Sonuç olarak, Akdeniz'in, Avrupa entegrasyonunu model olarak alan entegre bir alan olarak kurgulanmasının, Akdeniz ülkelerine samimi ve eşit koşullarda, açık bir perspektif sunulması kaydıyla, ortak sorunlara daha iyi çözümler bulunmasına katkıda bulunacağı önermesini ileri sürer.

Anahtar Kelimeler: Akdeniz, İşbirliği, güvenlik, göç, çevre, entegrasyon, mekan

* Istanbul Medipol Univesity, Department of Political Science and International Relations, migradenker@gmail.com,
* $\quad$ Marmara University, Department of Political Science and International Relations, edogan@marmara.edu.tr 


\section{Introduction}

The Mediterranean has not referred to a political unity except during Roman and Ottoman periods. It is referred to as "a concept, a center, a limit, or an edge" (Brummett, 2007, p. 9). Yet, it is more than all of these conceptualizations, and it is definitely more than just a sea. It is a broad maritime space where interaction, communication and movement of people, goods and other assets have always taken place. The idea of the Mediterranean as a space with common qualities like culture, climate, architecture, etc. has existed in the minds of early observers such as poets, novel writers, historians, geographers or political scientists since ancient times. Different visions and frames of the Mediterranean as a space are found on the eastern, northern and southern coastlines, in the writings of Ibn Khaldun, Ibn Battuta, Evliya Çelebi, Muhammad as-Saar, Braudel, and many others (Brummett, 2007). Similarly, early navigators of the Mediterranean such as sailors, merchants, slave traders or pirates would also have tended to see the sea as a common space in its totality or sub-regions like the Aegean, eastern Mediterranean, Adriatic and the shores of West North Africa, etc. over which they undertook their business. The actors of the Mediterranean found a climate/environment suited to the development of civilizations. Olives, olive oil, grapes, wine, palm trees, ivory, slaves and wheat were some of the most traded commodities. Catholicism, Orthodoxy, and Islam were the dominant religions and denominations. The Roman Empire, Carthage, and the Ottoman Empire were the states/empires that determined the agenda over and around this space for hundreds of years. Referring to rising tourism industry during the last half of the20th century, Henry Lefebrvre (1991, p. 353) claimed that Mediterranean transformed into a leisure oriented space. In sum, the Mediterranean has been a political space ${ }^{1}$ over which many different actors played different games, made calculations and taken actions.

Due to its characteristics, this space hosts both unity and diversity. While there is a physical and cultural unity in the region, there are ethnic, linguistic, religious, and political diversities. That is why the Mediterranean is often referred as both a bridge and a barrier (Tsardanidis and Guerra, 2000). In the end, what the Mediterranean will be, either a bridge or a barrier, is subject to the outcome of the interaction of those different actors at political, social and economic levels. The nature of these interactions - be they are peaceful, conflictual or hostile - will determine the level of suffering for the people.

The EU has had a bumpy relationship with the Mediterranean countries. When the EU Member States approached the Mediterranean and focused on cooperation with the launch of the EuroMediterranean Partnership first, and the idea of a Mediterranean Union later, they started from a different end. In line with their own integration experience, they had an institutional and a top down perspective. Though they tried to explore commonalities and common interests to achieve the potential for cooperation in the Mediterranean, there was no ideology or another drive like immediate short-term profit that would fuel this integration. In addition, the EU has been criticized for being highly EU-centric in these processes as well as for not paying real attention to

1 According to Edward W.Soja (1971, p. 1), political organization of space is characterized with the ways in which space and human interaction are structured to fulfill political functions. 
the Mediterranean. So what remains is a romanticized vision of a Mediterranean, best described in the words of Sarkozy (Charlton, 2008, p. 3):

"The European and the Mediterranean dreams are inseparable [...] We will succeed together; we will fail together. [...] We will build peace in the Mediterranean together, like yesterday we built peace in Europe [and that the Mediterranean Union would not be] north against south, not Europe against the rest ... but united."

As briefly discussed in this study, earlier multilateral cooperation attempts as well as the EuroMediterranean Partnership and the Union for the Mediterranean have all disappointed the participants in realizing this united Mediterranean vision where peace and prosperity reign. Yet there are urgent issues that call for attention and a concerted response, primarily security, terrorism, irregular migration, and environmental degradation. There are other problems, too, such as human trafficking, smuggling, problems with exploitation of the undersea basin, unstable undemocratic regimes in the south, economic crises in Greece, Spain, France and Italy, inequalities, status of women in the south, xenophobia in the north and the declining importance of the Mediterranean as the world's economic centre of gravity shifts east. Though the Mediterranean space loses its strategic advantage, the problems need cooperative solutions. Despite these problems, the advantages of the Mediterranean space offer a deepening and widening volume of trade, cultural interactions, tourism, newly discovered undersea resources, the sea being a common basin for fishing, mixing of people, cultural similarities, having been located at the centre of Africa, Europe and Asia, logistic advantages, population, labour, and intra-Mediterranean trade (still low). These advantages should motivate the actors to strive for integration in this space, or for the establishment of an integrated Mediterranean space, which might start as a loose functional integration in one area, such as migration or environment, and might spill over to other areas as occurred in Europe. Or it might start as a very loose regime in such an area, and remain so, in which parties interact, solve the problems and continue to do trade, make cultural, political, economic exchanges in harmony.

In line with these thoughts, this study starts by examining the prime challenges in the Mediterranean - security, migration and environment - and proceeds by discussing several multilateral cooperation programmes and frameworks in the region. Among these programmes and frameworks, the attention is on two ambitious initiatives: the Euro-Mediterranean Partnership, or the Barcelona Process, and the Union for the Mediterranean. As the study briefly discusses the failures of these initiatives, it questions whether two crises in the Mediterranean space, those of migration and environment, may trigger integration in this space. Following this discussion, the study concludes by putting forward some considerations on this hypothetical integrated Mediterranean space. The study is built on through examination of secondary literature on identified prime challenges, cooperation efforts and initiatives. Reports by several international organizations as well as those by the EU have been critically examined. 


\section{Prime Challenges in the Mediterranean}

As a sea, space, and region with porous borders, the Mediterranean faces several challenges that urge all countries with Mediterranean coastlines to consider cooperation seriously. The Mediterranean is co-possessed by more than 20 countries in three different continents: Europe, Africa and Asia. As shown in Figure 1, the number of countries in the European continent with Mediterranean coastlines exceeds those in Africa and Asia. Spain, France, Monaco, Italy, Malta, Slovenia, Croatia, Bosnia and Herzegovina, Montenegro, Albania, Greece, Cyprus, and Turkey are the European countries of Mediterranean. In addition, though it does not have a coastline on the Mediterranean, Portugal is also considered part of the region. To the south, Algeria, Egypt, Libya, Morocco, and Tunisia are the African countries with Mediterranean coastlines, while in Asia, Israel, Lebanon, and Syria share the Mediterranean.

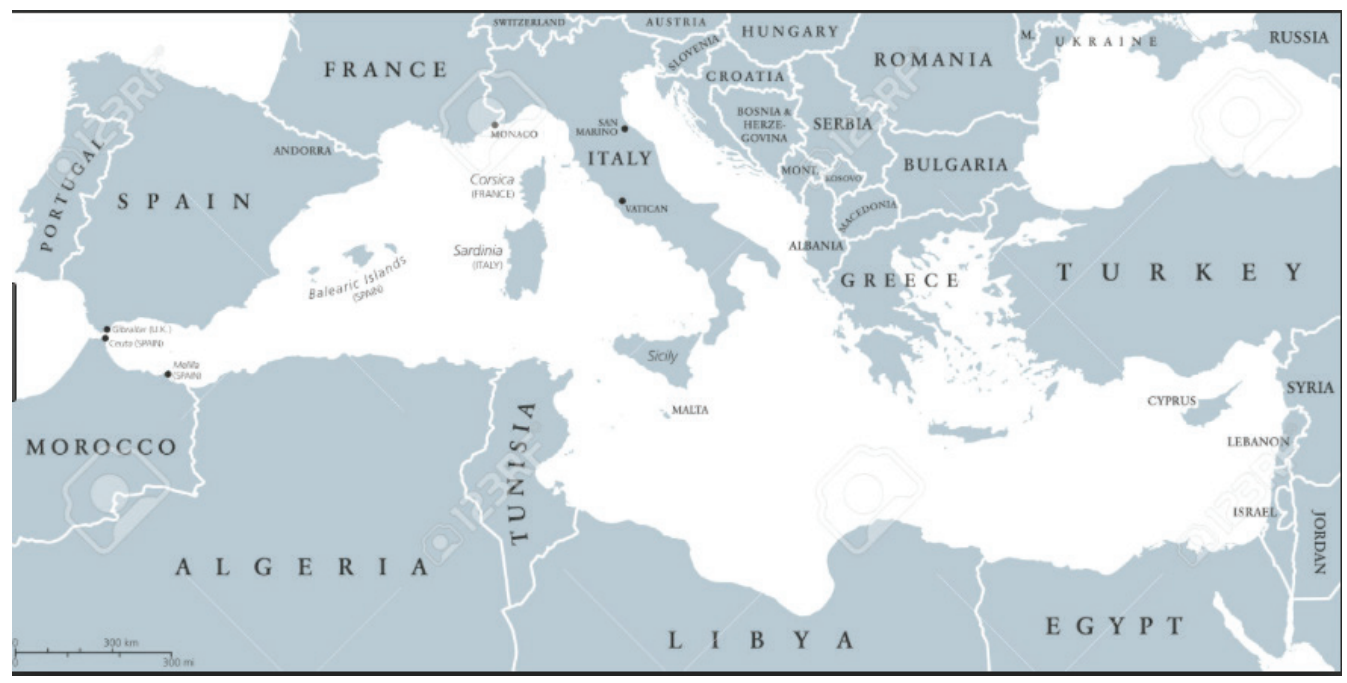

Figure 1: Mediterranean Countries. Source:http://www.istockphoto.com/tr/vektör/mediterranean-sea-region-countries-map-gm594478992-101950585

With such diverse littoral states with different levels and understandings of economic, political and societal development, the Mediterranean has been a centre for challenges. Moreover, the challenges have not been static, they have been dynamic as they have changed with the changing international conjuncture and priorities of the parties. As briefly discussed in the following section, several cooperation and dialogue processes have taken place since the end of the Cold War and the priorities of these processes are informative for the dynamic challenges that the space and/or region faces. It is understood that before the end of the Cold War, and in its early aftermath, the foremost concern was security in cooperation efforts. In 2001, just before September 11, Brauch (2001, p. 7) enumerated six long-term challenges of the Mediterranean in the $21^{\text {st }}$ century. These were: 
- Different levels of population growth between northern, southern and eastern shores;

- The impact of climate change on the temperature, precipitation and rise of the Sea level;

- The scarcity of water for drinking and irrigation;

- The decline of self-sufficiency in food production and the increasing need for imports of cereals;

- Soil erosion and desertification;

- Urbanization and pollution in the major cities on the eastern shores (Istanbul, Cairo, etc.).

Though these issue areas have kept their importance, September 11 deeply affected international relations in the region. In the post-September 11 context, the 'fight against terrorism' emerged as one of the prime concerns and has remained so until today. Since the early 2000s, cooperation efforts aimed to create conditions in which terrorism cannot flourish in the Mediterranean. In addition to the fight against terrorism, mobility in the Mediterranean has been the other important item in dialogue and cooperation efforts. Securitization of migration and concerns over irregular migration in the region have led to various forms of dialogue and partnership frameworks as well as institution building and operations by northern coastline states. Moreover, environmental degradation in the Mediterranean has become the following item in dialogue, cooperation and partnership efforts. Several environmental agencies have recognized the Mediterranean as a fragile eco-system with strained resources, and they have carefully monitored human activities with important causes for the degradation of this eco-system since the early 1990s (European Environment Agency, 2006). In addition to these three main issue areas - security, migration and the environment - sustainable development, energy, shared basin management, transport and logistics, the arms race, armed conflicts, democratization, human security, social protests and movements in the Arab countries, civil war in Syria, the Syrian refugee crisis, jihadism and international terrorism have demanded the utmost attention of the Mediterranean states.

\section{Security}

During the Cold War, security in the Mediterranean was discussed within the context of the East - West confrontation and the Middle East conflict. The dissolution of the Soviet Union has removed the Soviet threat and left a dynamic security environment, which has been changing since then. In this environment, the number of security issues has increased, and their nature has changed. During the 2000s, non-military security challenges came to the fore. In those years, Ormanc1 (2000) explains these challenges as the difference in economic development, Islamic fundamentalism, terrorism, organized crime, and drug trafficking, increasing military expenditures and the proliferation of Weapons of Mass Destruction and demographic imbalance. The 2010s witnessed social protests and movements in the Arab countries with coastlines on the Mediterranean. However, the hopes for democratic transition in these countries were dashed in only few years as they were driven to political instability. Several of these southern Mediterranean 
states have faced new destabilizing factors and have fallen prey to violence and terrorism. We should also highlight that the Mediterranean and its surrounding littoral states have suffered from high levels of military activity in the last decade. The war in Lebanon in 2006 was followed by foreign intervention in Libya in 2011 and the Syrian civil war is still ongoing.

Under these conditions, the Syrian civil war and its wider impact, ongoing instability in Libya, and its potential ramifications for the region, widespread violence, armed conflict, economic and social instability and increased activities of transnational terrorist networks in the Mediterranean are thought to be the most concerning security challenges today (Black, et al. 2017). Among these, terrorism deserves a few more words as it has become a real threat for the region.

Currently, the most significant terrorist threat in the Mediterranean emanates from the Islamic State in the Levant (ISIL). The group is also known as the Islamic State (IS), Islamic State of Iraq and al-Sham (ISIS), or Daesh (Irshaid, 2 December 2015). With origins in al-Qaeda, it emerged as a jihadist militant group in Iraq in 2013. After making territorial gains in Iraq, the group took control of some territory in Syria and proclaimed the establishment of a caliphate. The group aims to extend its so-called caliphate further into Syrian territory and poses a direct threat to countries adjacent to Syria and Iraq: such as Lebanon, Jordan, Turkey, Libya and Egypt (Black, et al., 2017, p. 12-15). The group has conducted deadly attacks against military, political and civilian targets not only in these countries but also in France, Spain, Germany, Belgium, Britain, Sweden, Russia and the US. Though its impact is lethal in all aspects of human life in the Mediterranean, ISIL is unfortunately believed to have gone global by perpetrating more than a hundred attacks in 30 countries killing thousands of people.

As shown in Figure 2, ISIL has had the most negative impact on the south-eastern Mediterranean countries (in red). While Turkey, France, Greece and Algeria have been affected by medium impact (in light orange), Spain, Italy, Tunisia, Albania, and Cyprus are reported to have a low impact of ISIL terrorism (in green). The group has carried out deadly attacks in all Mediterranean countries except Italy. As shown by the blue circles, the deadliest attacks have taken place in Egypt, Libya, Turkey, France, Syria, Tunisia and Algeria. 


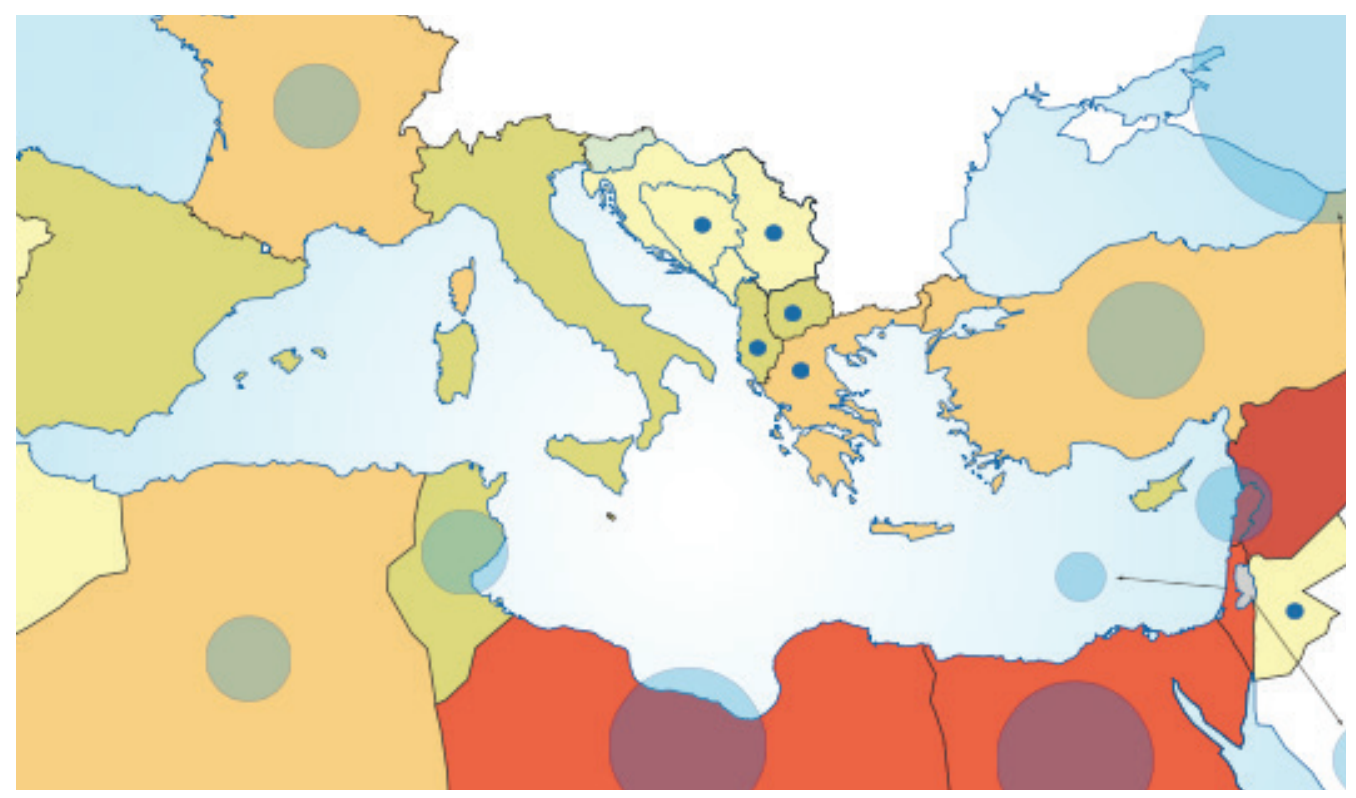

Figure 2: Terrorism in the Mediterranean. Source: IEMed Mediterranean Yearbook 2016.

\section{Migration}

As Haas (2011, p. 60-61) observes, since the 1950s migration dynamics within, from and towards the Mediterranean have fundamentally changed. These changes were not without reasons, they were triggered by the changes in the broader political and economic context of the region. Specifically, they were marked by the economic rise of the countries on the northern coasts and their accession to the EU as well as economic growth in the Gulf countries and Libya after 1973. In the 1990s, these countries emerged as new destinations for migrants from southern Mediterranean countries, as well as from sub-Saharan Africa and Asia (Castles, et al., 2013).

Moreover, economic growth and increasing demand for service sector employees in Spain, Portugal and later Turkey, pulled labour migrants from these countries (Baldwin-Edwards, 2005; İçduygu, 2005). As the demand for labour was not matched by sufficient legal channels of migration, these dynamics paved the way for irregular migration to these countries (Cornelius and Tsuda, 2004; İçduygu, 2005; Triandafyllidou and Vogel, 2010). In addition, North African migrants were joined by sub-Saharan Africans in their attempts to cross the Mediterranean by boats. As a response, northern coastline countries - many have already become EU members have intensified their border controls in order to curb irregular migration. Rather than curbing irregular migration, efforts to strengthen border controls and create impermeable borders have diversified migration routes in the Mediterranean (Gonzales-Enriquez, 2010; Triandafyllidou and Vogel, 2010). Concerns about irregular migration have paved the way for many operations as well as several partnership and cooperation initiatives in the Mediterranean. As the initiatives are 
discussed in the following paragraphs, the main concern was to regulate international migration flows destined for northern Mediterranean countries by curbing irregular migration flows from the southern and eastern coastlines (Geddes, 2005; Wolff, 2008). However, as highlighted by the International Organization for Migration (2008), despite 40 years of efforts irregular migration is far from waning. That is because, not only irregular migration but all flows of migration in the Mediterranean have been driven by factors of economic, political, demographic and environment as well as by the migration policies (Haas, 2011). This means that adopting exclusively securitized approaches to migration by neglecting the root causes and the drivers of the phenomenon in the region has had only negative consequences such as diversification of routes to dangerous ones, migrant deaths in the sea or in the hands of smugglers.

As observed very recently, among all these factors, state violence and wars have had a tremendous role in shaping migration processes in the region. The roles played by the Arab-Israeli conflict, the conflict around the Western Sahara, the civil wars in Algeria, Iraq and Syria cannot be denied in producing all types of migrants, but primarily refugees (Castles, et al., 2013). ${ }^{2}$ According to the United Nations High Commissioner for Refugees (UNHCR), the number of refugees in the world has reached 21.3 million, making Turkey, Pakistan, Lebanon, the Islamic Republic of Iran and Ethiopia top countries of asylum. The ongoing civil war in Syria has caused the worst refugee crisis of our time, making Syrian refugees the largest refugee community in the world. It is estimated that by December 2016, 12.5 million Syrians had been displaced since the conflict began in 2011. According to the United Nations High Commissioner for Refugees (UNHCR) there are 7.5 million internally displaced persons while over 4 million people have sought asylum in neighboring countries - Turkey, Egypt, Lebanon, Jordan and Iraq. Among these nations, Turkey is reported to host the largest number of Syrian refugees - almost 3 million as of May 2017. Lebanon hosts the second largest Syrian refugee community ( 1 million) in the region.

Refugees have become more prominent as they started to cross into Europe in large numbers in 2015. The majority of them arrived by sea, mainly from the Turkish coasts to the Greek islands, but also from Egypt, Libya and Tunisia to Italy. According to the UNHCR (2017), the number of sea arrivals, which was 216,350 in 2014 reached 1,015,953 in 2015 and then fell to 363,425 in 2016. In addition, thousands of migrants are thought to have drowned as they went missing in the Mediterranean during their dangerous journeys. Syrian refugees made up the majority among the refugees, followed by Afghans and Iraqis. Although the so-called "refugee crisis of 2015" has been taken under control, the civil war in Syria still continues with no imminent hope of peace. Many people continue to leave Syria or the places they sought asylum in the first place. The Mediterranean continue to host many refugees until their next destination.

21951 Convention relating to the Status of Refugees and its 1967 Protocol define a refugee as a person, who "owing to well-founded fear of being persecuted for reasons of race, religion, nationality, membership of a particular social group or political opinion, is outside the country of his nationality and is unable or, owing to such fear, is unwilling to avail himself of the protection of that country; or who, not having a nationality and being outside the country of his former habitual residence as a result of such events, is unable or, owing to such fear, is unwilling to return to it" (UNHCR, 2010, p. 14). 


\section{Environment}

The Mediterranean is threatened by environmental degradation due to population and urban growth, tourism, intensive agriculture and pollution, disposal of industrial and domestic waste and desertification. It has been identified as one of the areas most responsive to climate change. The region faces water stress, extreme climate events (such as floods and droughts), biodiversity decline, rise in temperature and sea level, air and water pollution and soil degradation (European Environment Agency, 2015, p. 1-2). In addition, the rivers feeding into the Black Sea are highly polluted due to the levels of industrialization in the coastline countries.

Water shortage in the region is a major concern. According to Plan Bleu (2017), southern coastline countries along the North African coast receive only one-tenth of the total rainfall in the region while coastal and island communities face serious water shortages, especially during the tourism season. Water stress in the region is expected to worsen with population growth, development of tourism and industry in the southern coastlines (ibid, p. 2-3). Moreover, demographic growth in the southern coastline states is expected to have very adverse effects on the environment. In addition to increased stress on water, demographic growth will raise the number of urban dwellers, as well as the problems of waste management and air pollution.

According to experts, the Mediterranean environment is recognized as one of the most vulnerable in the world. That is why despite their cultural, political and economic differences, Mediterranean states have been open to dialogue and cooperation. As discussed in the following pages, besides security and migration, the environment has become one of the key items in cooperation efforts.

\section{Quest for Strengthened Relations: The Road to Union for the Mediterranean}

In order to strengthen relations among Mediterranean countries, several initiatives have been undertaken since the early 1990s. It is possible to trace the early phases of efforts for cooperation in the Mediterranean from the 1970s. Since then, though all of their efforts have not born fruit, the Organization for Security and Cooperation in Europe (OSCE), the North Atlantic Treaty Organization (NATO), the Western European Union (WEU), the United Nations (UN), and the European Community (EC), later the European Union (EU) have become the leading actors in shaping issue-specific cooperation efforts.

OSCE's interest in the Mediterranean dates back to the Helsinki Final Act of 1975, which recognized that:

“...security in Europe is to be considered in the broader context of world security and is closely linked with security in the Mediterranean as a whole, and that accordingly the process of improving security should not be confined to Europe but should extend to other parts of the world, and in particular to the Mediterranean area" (OSCE, 2015, p. 14). 
Following the adoption of the Act, non-participating states were invited to take part in the meetings on Mediterranean issues. Participating states remained interested in the region and emphasized the need to involve the Mediterranean more with its 1990 Charter of Paris:

"We will continue efforts to strengthen security and cooperation in the Mediterranean as an important factor for stability in Europe (ibid, p. 16)."

Since then all following key documents of the OSCE have emphasized the Mediterranean and underlined the need to foster deeper relations with the non-participating states in order to generate security and cooperation in the region. Non-participant states in the Mediterranean have been invited to the meetings and they have been given the opportunity to submit opinions in different issue areas. It is also important to note that OSCE has promoted transparency and accountability and enhanced public confidence in electoral processes in non-participant Mediterranean states by sending observers for election monitoring and supervision (ODIHR, 2010).

NATO set its eyes on the Mediterranean twenty years later in 1994 when it launched its Mediterranean Dialogue (MD). The idea behind this process was the recognition that security in Europe is closely linked to security and stability in the Mediterranean. MD's aims are enumerated as "to contribute to regional security and stability", "to achieve better mutual understanding" and "to dispel any misconceptions about NATO among the participant countries". MD has also been considered an integral part of NATO's adaptation to the post-Cold War security environment (NATO, 2015, p. 4). Currently, besides its members, MD involves seven non-NATO countries of the Mediterranean: Algeria, Egypt, Israel, Jordan, Mauritania, Morocco and Tunisia (NATO, 2015 , p. 4). It promotes cooperation among participants in security-related issues via seminars, workshops, practical activities on the modernization of armed forces, civil emergency planning, crisis management, border security, environment, public diplomacy, counter terrorism, etc. (ibid, p. 5).

Similarly, the OECD and the UN have also been active in the region. The OECD has developed programmes devised to strengthen investment infrastructure in the southern coastline countries. The latest of these, the EU-OECD Programme, strives to promote investment in the Mediterranean by helping national and local actors in the region to modernize their investment policies, build institutional capacity and raise awareness of the region's attractiveness (OECD, 2016, p. 3). The UN, on the other hand, has initiated regional cooperative efforts in different issue areas. The environmental Mediterranean Action Plan by UN Environment Programme, Regional Refugee and Migrant Response by UNHCR and the Spring Forward for Women Programme a partnership on women's empowerment in the Mediterranean by UN Women are only three of these efforts. $^{3}$

Besides all these frameworks and initiatives, the EU has initiated two encompassing cooperation processes for the Mediterranean. The first was given impetus by the first Euro-Mediterranean

3 Spring Forward for Women was launched jointly by UN Women and the European Commission as a regional programme to promote gender equality and women's empowerment in the South Mediterranean countries. 
Conference in Barcelona in 1995. Having recognized the new political, economic and social issues on both sides of the Mediterranean and the common challenges they posed, partners called for a coordinated response. The call resulted in the Euro-Mediterranean Partnership, also known as the Barcelona Process. With its different aspects and novelties, the Barcelona Process was a unique and ambitious initiative, and it is still believed to represent a turning point in EuroMediterranean relations.

The process aimed to lay the foundations of a new regional relationship based on cooperation between the EU and 12 southern and eastern Mediterranean countries. In doing that, it focused on security and stability in the Mediterranean, on agreeing shared values and initiating a longterm process for promoting democracy, good governance and human rights and achieving satisfactory trading terms for the partners. The main objectives of the Process are codified as:

1. To put forth a common area of peace and stability through the reinforcement of political and security dialogue;

2. To construct a zone of shared prosperity through an economic and financial partnership and the gradual establishment of a free-trade area;

3. To trigger a process of rapprochement between peoples of the Mediterranean through a social, cultural and human partnership in order to encourage understanding between cultures and exchanges between civil societies.

Zaafrane and Majoub (2000, p. 10) presented these ambitious objectives of the process with the diagram below:

\begin{tabular}{|l|l|l|}
\hline Outcomes & Means & Mechanism \\
\hline Peace & Democracy & Dialogue \\
\hline Stability & Economic Development & Exchanges \\
\hline Shared prosperity & $\begin{array}{l}\text { Social, human and cultural } \\
\text { development }\end{array}$ & Cooperation \\
\hline
\end{tabular}

In their influential paper, the authors discussed whether these three objectives - peace, stability and shared prosperity - were separable, and noted that partial and interest-driven steps might lead the region to destabilization instead of promoting peace and stability. Another concern raised by the paper was 'the permanent concern' for 'equity' among the non-European partners. The authors called partners to act cautiously in order not to generate new fears about this permanent concern and noted that the Partnership must be governed by principles of cooperation and partnership (as declared in the Declaration) but not by a balance of power politics.

The impact of EU enlargement in culminating this quest for regional cooperation should not be overlooked. After their accession to the EC/EU in 1986, Spain and Portugal worked very hard to give the EU a Mediterranean angle in which their interests in the region would make a 
resonance within the EU system (Tovias, 2008). Besides the ambitions of these new members at the time, the Barcelona Process should also be considered within the international conjuncture. The fall of the Berlin Wall and the dissolution of the Soviet Union in the early 1990s brought new opportunities and challenges for all regions, including the Mediterranean. The EuroMediterranean Conference took place only two years after Samuel Huntington had shared his influencing clash of civilizations thesis, which argued that coming international conflicts would be shaped by culture and civilization. Amid discussions on the clash of civilizations preparing the ground for international conflicts, Javier Solana, Spanish Minister for Foreign Affairs and High Representative for the EU's Common Foreign and Security Policy, opened the conference saying that "they were brought together to straighten out the clash of civilizations and misunderstandings that there had been between them, and that it was auspicious that they had convened on the $900^{\text {th }}$ anniversary of the First Crusade" (Barcelona Process, 2001).

The Barcelona Process, or the Euro-Mediterranean Partnership began life with such high hopes, intentions and plans. However, only ten years later, by 2005, it was considered a disappointment. Borrell (2010), a former President of the European Parliament, explains that the process was born in the environment of optimism after the Oslo Peace Accords for the Middle East and it was already 'a mission impossible'. He claims that the failure of the peace accords rekindled conflict between Israel and Palestine, and later the war in Iraq generated "a confrontation between the western and Muslim worlds [and that] rendered the workings of the Barcelona Process almost impossible" (ibid, p. 3). EU enlargement to central and eastern Europe should also be kept in mind while the failure of the process is questioned. By the late 1990s, Europe had to direct its attention to former communist states in central and eastern Europe, which explained their aspirations to 'return to Europe' by joining the EU. As Borrell (2010) also notes, this enlargement process consumed much of the political energy and financial resources of the EU. In the end, as the planned steps were not taken, the Euro-Mediterranean Partnership or the Barcelona Process was not able to fulfil its promises and failed to realize its aims.

While the Euro-Mediterranean Partnership was largely considered a failure, the Mediterranean became a title/chapter in the new European Neighbourhood Policy (ENP) in 2003. The ENP's underlying thoughts were similar to the Euro-Mediterranean Partnership. It was about "avoiding the emergence of new dividing lines between the enlarged EU and its neighbours and instead strengthening the prosperity, stability and security of all" and the policy was "based on the values of democracy, rule of law and respect of human rights" (European Commission, 2016, p. 1). The ENP has its own mechanisms to reach these stated objectives.

In a way, the Mediterranean seemed to be downplayed within this policy. There was no specific emphasis on the Mediterranean in the ENP structure, and the region was not more important than any other neighbouring region. However, several developments have urged the EU to be more involved in the region since then. The 2004 Enlargement of the Union brought two more Mediterranean countries into the Union, Cyprus and Malta. A year later, Croatia and Turkey were recognized as candidates. Migration flows from southern coastlines to the EU have 
reached unprecedented levels. At the same time, environmental levels have been alarming and environmental degradation in the region has been pervasive, accelerating and putting people's health at risk. The failure of the Barcelona Process and these developments but also its interests in addressing domestic political concerns led Nicolas Sarkozy to call for a 'Mediterranean Union' in his campaign for the French presidential elections in 2007 (Balfour and Schmid, 2008). ${ }^{4}$ Though it was later diluted, Sarkozy's ambitious call for the 'peoples of the Mediterranean' led to the Union for the Mediterranean (UfM) (Gillespie, 2008). As discussed below, despite its novelties the UfM has proven less successful than its predecessor (Gillespie, 2013, 179).

\section{Disappointments in the UfM: What is wrong in the Mediterranean?}

Meeting in Brussels on 13-14 March 2008, the European Council approved the principle of a Union for the Mediterranean, but rather than replacing the Barcelona Process, the Council decided to integrate this new initiative into it. Following this decision, the Union for the Mediterranean (UfM) was created by 43 Euro-Mediterranean Heads of State and Government on 13 July 2008 at the Paris Summit for the Mediterranean. The UfM constitutes a framework for political, economic and social relations between the EU and the southern and eastern Mediterranean countries. As it was launched as a continuation of the Barcelona Process, the UfM shares its goals and aims to work towards the creation of peace, security and stability as well as sharing prosperity with the southern and eastern Mediterranean countries (UfM Secretariat, 2017).

In addition to giving a fresh impetus to the multilateral cooperation framework provided by the Barcelona Process, the UfM has brought several novelties. The introduction of a permanent institutional structure - a two-year Southern and Northern Co-Presidency and a secretariat to empower the regional dialogue among the Members and the stakeholders - are considered its two important institutional novelties. Bi-annual summits of the heads of state and government is another one. Membership of the UfM has expanded: 44 countries were invited to Paris and 43 of them subscribed to the final declaration. Libya opted to be an exception. It was recognized that the 'partnership' element between northern and southern countries remained weak under the Barcelona Process. The EU has been referring to the notion of 'co-ownership' within the ENP framework and this notion has been injected to the UfM as well (Gillespie, 2008; Balfour, 2009). Unlike the Euro-Mediterranean Partnership, the UfM's priorities have been clearly defined and the Secretariat will direct its attention to these issue areas and manage the projects related to them: "de-pollution of the Mediterranean Sea; maritime and land highways; solar energy; regional research programmes; joint civil protection programme for disasters; and business development for small and medium-sized enterprises" (UfM Parliamentary Assembly, 2017, p. 1).

As Gillespie (2013) notes, in a very short period of time, the UfM followed the earlier multilateral cooperation frameworks in disappointing its participants. In his words, it has proven to be less

4 It is thought that in addition to provide cooperative solutions to common problems, the proposal was aimed to restore France's leading position in Europe and in the Mediterranean (Joffe, 2008; Doğan, 2008). 
successful than the Barcelona Process (ibid, 179). Several reasons are discussed for the failure. The primary factor is considered to be the EU-centric approach towards the neighbouring regions. Another reason is the different levels of strength among EU member states. Mediterranean members of the EU are relatively weak and dependent on the North. They do not have a high degree of autonomy vis-à-vis other Europeans to develop and continue a fullfledged Mediterranean program. They need to accommodate the fears, concerns and calculations of the north too. Therefore, Mediterranean members of the EU cannot focus solely on the Mediterranean. Mediterranean members of the EU do not see the rest of the Mediterranean as equal. They just want the others to follow and be dependent on their terms which are not decided by themselves alone but together with the other EU members (Doğan, 2008).

Another reason for the failures is the imbalance and radical inequality among the countries on the Mediterranean. Inequalities make it difficult to come together and establish a union. As shown in Figure 3 below, the south is weak, poor, demographically young, and politically instable.

\begin{tabular}{|c|c|c|c|c|c|}
\hline $\begin{array}{l}\text { Medit e r r a n e a } \mathrm{n} \\
\text { Countries }\end{array}$ & $\begin{array}{l}\text { GDP per capita } \\
(\$, 2016)\end{array}$ & $\begin{array}{l}\text { Population } \\
\text { (in thousands) }\end{array}$ & $\begin{array}{l}\text { Percentage of total } \\
\text { population under } 15 \text { years }\end{array}$ & $\begin{array}{l}\text { Percentage of } \\
\text { Total Population } \\
\text { in Urban Areas }\end{array}$ & $\begin{array}{l}\text { Literacy rate } \\
(+15)\end{array}$ \\
\hline Portugal & 19,813 & 10,699 & 15 & 62 & 95 \\
\hline Spain & 26,529 & 46,772 & 15 & 78 & 98 \\
\hline France & 36,855 & 63,458 & 18 & 86 & 99 \\
\hline Monaco & 162,009 & 36 & 13 & 100 & 99 \\
\hline Italy & 30,527 & 60,964 & 14 & 69 & 99 \\
\hline Malta & 25,058 & 469 & 14 & 95 & 92 \\
\hline Slovenia & 21,304 & 2,040 & 14 & 50 & 100 \\
\hline Croatia & 12,091 & 4,387 & 15 & 58 & 99 \\
\hline Bosnia \& Herzegovina & 4,709 & 3,744 & 14 & 49 & 98 \\
\hline Montenegro & 6,701 & 633 & 19 & 63 & 98 \\
\hline Albania & 4,147 & 3,227 & 22 & 55 & 96 \\
\hline Greece & 18,104 & 11,419 & 15 & 62 & 97 \\
\hline Turkey & 10,788 & 74,509 & 26 & 72 & 91 \\
\hline Cyprus & 23,324 & 1,129 & 17 & 71 & 98 \\
\hline Syria】 & $\cdots \cdots$ & $\ldots$. & 35 & 56 & 86 \\
\hline Lebanon & 7,914 & 4,292 & 24 & 87 & 90 \\
\hline
\end{tabular}




\begin{tabular}{|l|l|l|l|l|l|}
\hline Israel & 37,293 & 7,695 & 27 & 92 & 98 \\
\hline Egypt & 3,515 & 83,958 & 31 & 44 & 72 \\
\hline Libya & $\ldots \ldots$ & $\ldots \ldots$ & 31 & 78 & 89 \\
\hline Tunisia & 3,689 & 10,705 & 23 & 67 & 78 \\
\hline Algeria & 3,843 & 36,486 & 27 & 74 & 73 \\
\hline Morocco & 2,832 & 32,599 & 27 & 57 & 56 \\
\hline
\end{tabular}

Figure 3: Economic and Social Indicators, Mediterranean Countries. Source: The World Bank, 2017; UN, 2012. * before the civil war

Yet despite these indicators, southern Mediterranean states are sovereign and they do not want to be totally dependent on the north. They need to be negotiated with and convinced. The European defenders of a Mediterranean Union are not powerful enough to convince the south to take part in this union. In addition, there are other players in the region like the US, Russia and China and their position on the establishment of a Union should also be analysed. Considering all these indicators, we note the complicated nature of the relations in the region with an emphasis on the lack of European absolute superiority in the Mediterranean.

Moreover, the countries in the region are governed by a variety of regimes ranging from democratic monarchies to authoritarian republics. It is difficult to close the gap between democracies and non-democracies. These regimes are quite incompatible with those on the northern coastline. Southern Mediterranean countries and those located in the north, most of which are EU members, have different priorities and mental settings. Therefore, developing a common lingua over which cooperation and exchanges would be possible is a difficult task.

Arab states on the southern coastline, literally and politically speak the same language. Italian, French and Spanish are not too distant languages and the regime types and political culture of those European Countries are quite similar. Israel, Turkey and Greece on the eastern Mediterranean are more distant in terms of languages. However, culturally they would be considered similar to each other with Israel being an exception as an extraordinary intervention in the course of history.

Political and societal developments on both sides should also be emphasized. Political Islam as an ideology and its projects on the southern coastline countries, with rising xenophobia and political, ideological and economic crises of the West on the northern coastline EU member countries are not easy to accommodate. Under these conditions, we may consider the subregional integration projects of the Maghreb, Mashreq, Levant, Adriatic, and the Aegean rather than an 'encompassing Union' for the region as a whole. 


\section{Migration and Environment Crises: Leverage for Cooperation?}

Crises refer unexpected and sudden but unmanageable changes in large volume. They are basically indicators of insufficiency of existing institutional structures vis-a-vis new developments. Crises are not always so bad. They are also indicators of a need for change. A crisis situation is one when actors could not continue with the existing status quo.

When the environmental degradation and the migration crisis in the Mediterranean are considered, the steps expected to be taken are questioned. In other words: the question is whether the northern coastline countries - almost all are EU members - will turn a blind eye and expect the outcome of these crises to hit them or whether they will use these crises as leverage for a radical transformation.

What Europe is trying to do at the moment with migration is to stop it by means of security measures. What should have been done on the other hand is to work to better those conditions that lead to massive human mobility before they rise and become acute (Doğan, 2008).

People have different motivations for moving, such as security, a better economic and social life, better educational opportunities, or more freedom. Many people from the southern coastline countries as well as from sub-Saharan Africa are moving towards northern coastline countries but also to other southern countries with these motivations. If migrants are provided similar conditions to those of the destination countries at home, they would not prefer to migrate. So, the northern Mediterranean that wants to regulate migration at home, has to work stronger for the betterment of the origin countries, primarily those on the southern coastline of the Mediterranean.

Firstly, they have to work to strengthen democracy in these countries without having secondary thoughts. This means that they should not approach democracy as a tool to penetrate other countries and increase their own short term gains and maximize their own short term interests. Their long-term interests lie in the development of democracy in the South and that would give people relief. The curse of colonialism will follow ex colonizers up until they pay back the last penny they stole from their colonies. ${ }^{5}$

Secondly, security has to be prioritized and democracy promotion should not jeopardize the security of people in any condition. Democracy promotion should not encourage minorities for independence, either. While we try to minimize the bullying undemocratic activities of the states, we should not allow a process that creates more insecure and more oppressive states. Confidence building among different communities, promotion of rights of minorities, minimizing oppression by the states and any other group that resorts to violence should be the priorities of the EU while projecting its preferences and might to other regions.

5 An adopted quote from Pirates of Caribbean - The Curse of the black pearl. 
Regarding the environmental crises, the EU's efforts have hardly been a success. As noted above, the Mediterranean is becoming dirtier, fish stock and biological life are deteriorating. Europe's Mediterranean members' capabilities are limited. They are calling on other members for cooperation. As they do not have enforcement mechanisms and capabilities, the impact of this call is minimal. However, environmental levels are alarming and Mediterranean countries have to cooperate to develop institutional mechanisms to help the environment.

\section{Conclusion: Not a Union, but an Integrated Space?}

Despite the negativities that dominate the debate on what has been happening over the Mediterranean, this might, unexpectedly, create a window of opportunity for the creation of an integrated Mediterranean space as well. Europeans other than Mediterranean ones would be forced to think Mediterranean-wise. They should think about the problems of people over the non-European parts of the Mediterranean and be compelled to produce solutions to the problems of these people. This activity would lead to the formation of institutions and through these institutions all Europeans would communicate more and this process would lead to the formation of a more interrelated and then integrated Mediterranean space.

When the European political landscape and existing patterns are studied, it is understood that the European way of approaching problems is securitization in the first place. Paradoxically, this might lead to further conflicts and more sophisticated breaches of European security. The current policy choices of the European states, including the northern Mediterranean states, over migration crisis are explained by this approach. Migration is a highly securitized issue in Europe. EU member states are trying to manage migration with securitized regimes and policies. However, this option is unsustainable. In our hypothetical integrated Mediterranean space, the northern coastline, EU Mediterranean countries could opt to deal with migration at source countries through political and economic means. This approach would inevitably entail policies for political and economic restructuring at source countries. These policies would be devised according to the problems, needs and crises of the origin countries. If they were designed to please only the destination countries - EU members in our discussion - then they would be temporary and complicate the problem, further.

To reiterate once again, after the major crises there exists a window of opportunity. This opportunity can be utilized if there is a willing leadership. It could be created under the leadership of a major power, like the EU or some of the EU member states that are ready to take the lead. But if the power that plays leadership is not that powerful and convincing enough, its efforts will be useless as it will not convince others. When we consider the Mediterranean countries, we do not see such leadership potential in terms of capacity and capabilities in any of the southern coastline states. Though they have strategic interests in the region, neither the US nor Russia are Mediterranean countries. In the end, we once again turn to the north, to the EU. There is no other potential actor, therefore the EU has to assume this leading role. 
Under such leadership of the EU, integration of the Mediterranean space might start as a very loose functional integration and might spill over to other areas as occurred in Europe. Or it might start as and remain a very loose regime in which parties interact only for trade, to make cultural, political and economic exchanges in harmony. In either case, there should be freedom of movement for goods, services, capital and human beings. Without free movement of factors of production, integration at social and economic level cannot be provided. And the rest of the Mediterranean cannot feel themselves as equals. If the southern and eastern Mediterranean are not respected and they cannot have a fair share of economic, cultural and political resources as equals then there will not be any improvement in the level of integration.

\section{References}

Baldwin-Edwards, M. (2005). Migration in the Middle East and the Mediterranean, 1-38. Geneva: Global Commission on International Migration.

Balfour, R. (2009). The Transformation of the Union for the Mediterranean: Profile. Mediterranean Politics, 14(1), 99-105.

Balfour, R., \& Schmid, D. (2008). Union for the Mediterranean, disunity for the EU. EPC Policy Brief.

Barcelona Process, (2001). http://www.barcelona.com/barcelona_news/the_barcelona_process_o r_euro_ mediterranean_partnership (accessed 8 July 2017).

Black, J., et al. (2017). Troubled waters: a snapshot of security challenges in the Mediterranean region. California: Rand Corporation.

Borrell, J. (2010). "Yes the Barcelona Process was "mission impossible", but the EU can learn from that", Global Europe, http://europesworld.org/2010/10/01/yes-the-barcelona-process-was-missionimpossible-but-the-eu-can-learn-from-that/\#.WWFNHMbBL-Y (accessed 8 July 2017).

Brauch, H. G. (2001). 'What is the Mediterranean?' Paper presented in Canterbury Workshop - Security and the Environment in the Mediterranean in the $20^{\text {th }}$ Century, 8-10 September 2001.

Brummett, P. (2007). Visions of the Mediterranean: A classification. Journal of Medieval and Early Modern Studies, 37(1), 9-55.

Castles, S., Haas, H. \& Miller, M. J. (2013). The Age of Migration: International Population Movements in the Modern World, Hampshire: Palgrave Macmillan.

Cem Taha, İ. N. (2005). Interview with Dr. Javier Solana, http://www.global-leaders.tv/en/archive/javier_ solana.asp, (accessed 7 July 2017).

Charlton, A. (2008). 'Sarkozy launches union for Mediterranean region', Boston News, http://archive.boston. com/news/world/europe/articles/2008/07/14/sarkozy_launches_union_for_mediterranean_ region/ (accessed 02 August 2017).

Cornelius, W. A., \& Tsuda, T. (2004). Controlling immigration: The limits of government intervention. Controlling immigration: A global perspective, 2, 3-48.

Doğan, E. (2008). 'The Idea of Mediterranean Union and Turkey', Global Strateji Dergisi 4 (14), 96-103.

European Commission, (2016). 'European Neighborhood Policy', https://ec.europa.eu/neighbourhoodenlargement/neighbourhood/overview_en (accessed 28 July 2017).

Euro-Mediterranean Conference, (27-28 November 1995). Barcelona Declaration.

European Environment Agency (2006). Priority Issues in the Mediterranean. No 4/2006. Copenhagen: European Environment Agency. 
European Environment Agency (2015). 'Mediterranean Sea Region', https://www.eea.europa.eu/soer-2015/ countries/mediterranean (accessed 23 July 2017).

Geddes, A. (2005). 'Europe's Border Relationships and International Migration Relations' in Journal of Common Market Studies, Vol. 43, No. 4, 787 - 806.

Gillespie, R. (2008). A 'Union for the Mediterranean'... or for the EU? Profile. Mediterranean Politics, 13(2), 277-286.

Gillespie, R. (2013). The challenge of co-ownership in the Euro-Mediterranean space. Geopolitics, 18(1), 178-197.

Gonzales-Enriquez, C. (2010). Spain: Irregularity as a Rule. In A. Triandafyllidou (ed.) Irregular Migration in Europe: Myths and Realities (pp.247-267). Farnham: Ashgate.

Haas, H. de (2011). 'Mediterranean migration futures: Patterns, drivers and scenarios', Global Environmental Change, Vol. 21, 59-69.

İçduygu, A. (2005). Transit migration in Turkey: Trends, patterns and issues.

IEMed. (2016). Mediterranean Yearbook 2016. Barcelona: IEMed.

International Organization for Migration (IOM). (2008). World Migration Report 2008: Managing Labour Mobility in the Evolving Global Economy, Geneva.

Irshaid, F. (2 December 2015). 'Isis, Isil, IS or Daesh? One group, many names', BBC News, http://www.bbc. com/news/world-middle-east-27994277 (accessed 20 July 2017).

Joffe, G. (2008). 'Whiter Sarkozy’s Mediterranean Union?' http://carnegieendowment.org/sada/?fa=20519 (accessed 28 July 2017).

Lefebvre, Henri (1991). The Production of Space. Blackwell: Oxford UK, Cambridge US.

Lutterbeck, D. (2006). Policing migration in the Mediterranean: ESSAY. Mediterranean politics, 11(1), 5982.

Lutterbeck, D. (2006). Coping with Europe's boat people. Trends and policy dilemmas in controlling the EU's Mediterranean borders. Mediterranean Politics, 11(1), 59-82.

Lutterbeck, D., \& Engelbrecht, G. (2009). The West and Russia in the Mediterranean: Towards a Renewed Rivalry?. Mediterranean Politics, 14(3), 385-406.

NATO. (2015). 'NATO Mediterranean Dialogue', http://www.nato.int/cps/en/natohq/topics_60021.htm? (accessed 13 July 2017).

ODIHR. (2010). Election Observation Handbook. Warsaw: OSCE.

OECD. (2016). Promoting Investment in the Mediterranean. https://www.oecd.org/investment/PromotingInvestment-in-the-Mediterranean-EN.pdf (accessed 25 July 2017).

Ormanc1, B. (2000). Mediterranean Security Concerns and NATO's Mediterranean Dialogue, Paper submitted to the North Atlantic Treaty Organization.

OSCE. (2015). The OSCE Mediterranean Partnership for Cooperation: A Compilation of Relevant Documents and Information. Vienna: OSCE.

Plan Bleu (2017). 'Environment and Development in the Mediterranean', http://planbleu.org/en/activites/ water (accessed 23 July 2017).

Soja, E.W. (1971). The Political Organization of Space. AAG Resource Paper. No:8. Washington D.C.

The World Bank (2017). GDP Per Capita. http://data.worldbank.org/indicator/NY.GDP.PCAP. CD?locations=AL-MC (accessed 25 July 2017).

Tovias, A. (1998). 'Spain's input in shaping the EU's Mediterranean Policies, 1986 - 1996' in Mediterranean Historical Review, Vol. 13, No. 1 - 2, 216 - 234. 
Triandafyllidou, A. \& Vogel, D. (2010). Irregular Migration in the European Union: Evidence, Facts and Myths. In A. Triandafyllidou (ed.) Irregular Migration in Europe: Myths and Realities (pp. 291 - 299). Farnham: Ashgate,

Tsardanidis, C. \& Guerra, S. (2000). The EU Mediterranean States, the Migration Issue and the 'Threat' from the South'. In R. King and G. Lazaridis (eds.) Eldorado or Fortress: Migration in Southern Europe (pp. 321 - 34). New York: Palgrave Macmillan.

UfM Secretariat. (2017). History of the Union for the Mediterranean. http://ufmsecretariat.org/history/ (accessed 28 July 2017).

UfM Parliamentary Assembly. (2017). Background of the Union for the Mediterranean. http://www.paufm. org (accessed 28 July 2017).

UN (2012). Social Indicators. https://unstats.un.org/unsd/demographic/products/socind/ (accessed 25 July 2017).

UNHCR. (2010). Convention and Protocol Relating to the Status of Refugees. http://www.unhcr.org/protect/ PROTECTION/3b66c2aa10.pdf (accessed 11 August 2017).

UNHCR. (2017). Mediterranean Situation: Arrivals by Sea. https://data2.unhcr.org/en/situations/ mediterranean (accessed 22 July 2017).

Wolff, S. (2008). 'Border Management in the Mediterranean: internal, external and ethical challenges', Cambridge Review of International Affairs, 21 (2), 253-271.

Zaafrane, H., \& Mahjoub, A. (2000). The Euro-Mediterranean free trade zone: Economic challenges and social impacts on the countries of the South and East Mediterranean. Mediterranean Politics, 5 (1), 9-32. 